\title{
Differences in Incidence and Biological Characteristics of Breast Cancer between Roma and Non-Roma Patients in Slovakia
}

\author{
Rozdiely v incidencii a biologických charakteristikách \\ karcinómu prsníka medzi rómskymi a nerómskymi pacientkami \\ na Slovensku
}

\author{
Reckova M. ${ }^{1,2}$, Mardiak J. ${ }^{1}$, Plank L. ${ }^{3}$, Vulevova M. ${ }^{4}$, Cingelova S. ${ }^{1}$, Mego M. ${ }^{1}$ \\ $12^{\text {nd }}$ Department of Medical Oncology, Faculty of Medicine, Comenius University, National Cancer Institute, Bratislava, Slovak Republic \\ 2 POKO Poprad, s.r. O., Slovak Republic \\ ${ }^{3}$ Department of Pathology, Jessenius Faculty of Medicine in Martin, Comenius University in Bratislava, Slovak Republic \\ ${ }^{4}$ Department of Pharmacy, Comenius University in Bratislava, Slovak Republic
}

\section{Summary}

Background: Roma (Gypsies) constitute one of the largest ethnic minorities in Slovakia. Some reports have supported a higher prevalence of communicable diseases in Roma but data on cancer prevalence in Roma is absent. The aim of this study was to compare differences in the incidence and pathological characteristics of breast cancer between Roma and non-Roma in Slovakia. Patients and Methods: Roma and non-Roma breast cancer patients were identified using the Slovak HER2 Registry. The database from the last Census of Slovakia in 2011 was matched by gender, date of birth, and residency with the HER2 Registry from 2011 to 2013. Based on the match, Roma and non-Roma breast cancer patients were identified. Results: Thirty-two and 5,775 women with breast cancer were identified as Roma and non-Roma, resp. The age-standardized breast cancer incidence rate was 2.12 times higher for non-Roma than for Roma patients ( 36 vs. 17 per 100,000 people). Roma patients were younger than non--Roma patients (median 49 vs. 61 years; $p=0.00001$ ). Roma patients had more hormone receptor negative $(34.4 \%$ vs. $18.1 \% ; p=0.03)$ and triple negative tumors $(28.1 \%$ vs. $12.3 \% ; p=0.01)$ than non-Roma, and these differences remained statistically significant in multivariate analysis. Conclusion: For the first time, this study has revealed that the incidence and biological characteristics of breast cancer are different between Roma and non-Roma. Our data suggests that Roma patients are younger at diagnosis, have a lower age-standardized breast cancer incidence rate, and have more aggressive tumors than non-Roma.

Key words

breast neoplasms - incidence - Roma - epidemiology
Conflict of interest statement:

M. R., J. M., S. C. and M. M. have declared no conflict of interests. L. P. is a professional guarantee, he is employed and has a partial stock ownership at the Martin's Biopsy Center Ltd. in the past he has received honoraria from Roche Slovakia. M. V. was employed at Roche Slovakia within the past 2 years.

M. R., J. M., S. C. a M. M. deklarujú, že v súvislosti s predmetom štúdie nemajú žiadne komerčné záujmy. L. P. je odborný garant, zamestnaný a spolumajitel' Martinského bioptického centra, s.r.o.; $\vee$ minulosti dostal finančnú odmenu od spoločnosti Roche Slovensko. M. V. bola $\checkmark$ posledných 2 rokoch zamestnaná v spoločnosti Roche Slovensko.

The Editorial Board declares that the manuscript met the ICMJE recommendation for biomedical papers.

Redakční rada potvrzuje, že rukopis práce splnil ICMJE kritéria pro publikace zasílané do biomedicínských časopisů.

Maria Reckova, MD

POKO Poprad, s. r. o.

Mnohelova 2

05801 Poprad

Slovak Republic

e-mail:mreckova@gmail.com

Submitted/Obdrženo: 29. 8. 2016 Accepted/Príijato: 26. 10. 2016 


\begin{abstract}
Súhrn
Východiská: Rómovia tvoria jednu z najväčších etnických minorít na Slovensku. Existujú údaje o vyššej prevalencii prenosných ochorení u Romov, zatial'čo údaje o nádorových ochoreniach v rómskej populácii známe nie sú. Ciel'om tejto štúdie bolo porovnat' rozdiely v incidencii a patologických charakteristikách medzi rómskymi a nerómskymi pacientkami s nádorom prsníka na Slovensku. Materiál a metódy: Na základe údajov o pohlaví, dátumu narodenia a bydliska sme spárovali databázu HER2 registra v rokoch 2011-2013 s posledným sčítaním liudu Slovenskej republiky v roku 2011, a identifikovali sme rómske a nerómske pacientky s karcinómom prsníka. Výsledky: Identifikovali sme 32 rómskych a 5775 nerómskych pacientok s karcinómom prsníka. Vekovo-štandardizovaná incidencia karcinómu prsníka bola 2,12-krát vyššia u nerómiek v porovnaní s rómkami (36 vs. 17 na 100000 ludí). Rómky boli v čase diagnózy mladšie v porovnaní s neRómkami (medián 49 vs. 61 rokov; $p=0,00001$ ). Rómky mali v porovnaní s nerómkami viac hormón-receptor negatívnych (34,4 vs. $18,1 \% ; p=0,03)$ a triple-negatívnych nádorov $(28,1$ vs. $12,3 \% ; p=0,01)$, a tieto rozdiely zostali štatisticky signifikantné $v$ multivariačnej analyze. Záver: Poprvykrát sme zistili rozdiely $v$ incidencii a biologických charakteristikách u rómskych žien s karcinómom prsníka v porovnaní s nerómskymi pacientkami. Na základe zistených údajov predpokladáme, že rómske pacientky s karcinómom prsníka sú mladšie v čase diagnózy, majú nižšiu vekovo-štandardizovanú incidenciu a biologicky agresívnejšie nádory v porovnaní s nerómkami.
\end{abstract}

Klúčové slová

nádory prsníka - incidencia - Rómovia - epidemiológia

\section{Introduction}

Roma (Gypsies) constitute one of the largest ethnic minorities in Slovakia. They originally came from Northern India and nowadays about 12 million Roma people live worldwide [1]. Roma people have been the subject of stigmatisation and isolation from the majority population throughout history [1]. It is estimated that more than 400,000 Roma live in Slovakia [2]. However, in the last official Slovak Census in 2011 only $2.8 \%$ of the Slovak population identified their Roma ethnicity [3].

Roma people have poorer education and poor education is closely associated with many social and health problems [4]. It is believed that the health of Roma people is poorer than the health of the majority of the population, however these inequalities have not been sufficiently studied. One of the problems in executing a study in the Roma population is that data could be misused and the Roma could be stigmatised. Thus, Roma ethnicity has not been generally recorded and studied in the clinical trials [1]. Evidence also exists about poor communication between Roma and healthcare workers and low realisation of preventive care, including vaccination and screening programmes in Roma [1].

Most studies published on Roma health are on communicable diseases, however they are mostly community studies with limited sample size $[1,5,6]$. The available evidence suggests a higher predisposition of Roma to outbreaks of infectious diseases, especially those that are associated with unsanitary conditions and low rate of vaccination, as well as possibly a higher risk of contracting human immunodeficiency virus [1,5-16].

Data suggest higher rates of non-communicable and chronic diseases in Roma when compared with the majority population. However, the generalisability of most studies is limited due to the large non-response rate, small sample sizes and no adjustment for confounders [6]. Higher rates of diabetes mellitus and obesity, high blood pressure, end-stage renal disease and metabolic syndrome have been reported in Roma when compared to non-Roma [17-22]. Risky health behaviour was observed in Roma with a diet high in animal fat, low in fruits and vegetables, a high prevalence of smoking history and low physical activity [23].

There have been disparities reported in treatment outcomes and biology of oncology diseases in different racial and ethnic groups. For example, African American women have a lower lifetime incidence of breast cancer (BC) than white women, however the risk of $B C$ mortality and incidence in ages less than 45 years is higher $[24,25]$. African American women are also more likely diagnosed with $B C$ at an advanced stage and tumors are more likely to be poorly differentiated and triple negative (TN) when compared with tumors in white women. These biological features were also more commonly observed among women from western, sub-Saharan Africa who share common ancestry with African American women [26]. Finally, it was also reported that African Americans with $B C$ were less likely to receive optimal care compared with Caucasian Americans and this might contribute to poorer outcomes.

Oncology diseases have been practically unstudied in the Roma population and only one study from the Czech Republic reported on the incidence of cervical cancer, which was 26.2 per 100,000 non-Roma, but only 2.4 per 100,000 Roma women [1].

It is therefore the aim of this study to compare incidence and pathological characteristics between Roma and non-Roma BC patients in Slovakia.

\section{Patients and Methods \\ Patients}

All $B C$ patients registered in the HER2 Registry from 2011 through 2013 with complete information about histology, date of birth, gender and address were included. All people who identified themselves as having Roma nationality or speaking the Roma language were selected from the last Slovak Census in 2011 (SC2011) and identified as Roma people. The Roma female patients for our study were identified based on matching, gender, date of birth and address, of all patients registered in the HER2 Registry from 2011 through 
2013 with Roma people identified in the SC2011. Non-Roma patients were identified as all patients except Roma patients. Age at diagnosis, age-standardised incidence (ASI), histological and biological characteristics of Roma patients were then compared with non-Roma patients.

The Ethics Committee of the National Cancer Institute in Bratislava approved the study.

\section{HER2 Registry}

HER2 Registry collects data from the files in information systems of all pathology departments and laboratories in Slovakia examining either core-cut or resection biopsies of patients with BC verified by biopsy. This centralised Registry was founded in January 2003. Data integrity is based on the Formulary of the Registry requiring entry of identical algorithmically standardised data for every patient.

Carcinoma type, grade, stage, expression of ER (estrogen receptor), PR (progesterone receptor), Ki-67 antigen, as well as HER2 protein verified by immunohistochemistry, in cases with HER2 protein expression at 2+ level data on in situ hybridisation analysis of HER2 gene status (by FISH or DDISH analysis) are recorded in the Registry.

\section{Slovak Census}

The last official Slovak Census in 2011 (SC2011) included an extensive statistical inquiry in order to get data about the size of the population, and the population's demographic, educational, social and economic structure [3].

\section{Statistical analysis}

Patient characteristics were tabulated. The patients' characteristics were summarised using the mean, median and range for continuous variables and frequency (percentage) for categorical variables. Normality of distribution was tested by the Kolmogorov-Smirnoff test. Patients' age categories distribution and biological characteristics differences were tested by Fisher's exact test in univariate analysis. Logistic regression model was used in multivariate analysis.

The age-standardised incidence rate (ASIR) is defined as a summary measure

Tab. 1. Age distribution of the analyzed populations.

\begin{tabular}{l|cc}
\hline Age & $\begin{array}{c}\text { Roma patients } \\
\text { absolute number (\%) }\end{array}$ & $\begin{array}{c}\text { Non-Roma patients } \\
\text { absolute number (\%) }\end{array}$ \\
\hline all patients & $32(100.00)$ & $5,775(100.00)$ \\
\hline $20-29$ years & $1(3.13)$ & $22(0.35)$ \\
\hline $30-39$ years & $3(9.37)$ & $289(4.54)$ \\
\hline $40-49$ years & $13(40.62)$ & $881(13.85)$ \\
\hline $50-59$ years & $11(34.38)$ & $1,612(25.35)$ \\
\hline $60-69$ years & $0(0.00)$ & $1,886(29.65)$ \\
\hline $70-79$ years & $3(9.37)$ & $1,210(19.03)$ \\
$\geq 80$ years & $1(3.13)$ & $460(7.23)$ \\
mean (range) years & $51(22-81)$ & $61(22-96)$ \\
median & 49 & 61 \\
\hline p $=0.00001$ & & \\
\hline
\end{tabular}

of the rate that a given population would have if it had a standard age structure. The ASIR is a weighted mean of the agespecific rates; the weights are given by population distribution of a standard population. Slovak Population in 2011 was used as a standard population. The age-standardised incidence rate is expressed per 100,000 people.

All $p$ values presented are two-sided, and associations are considered significant if the $p \leq 0.05$. The IBM SPSS Software was used for analysis.

\section{Results}

Based on data from the SC2011, 151,128 of 5,404,322 Slovak people identified themselves as having Roma nationality or as speaking the Roma language.

There have been 10,344 records entered in the HER2 Registry from 2011 through 2013. By exclusion of more than one record in one patient $(1,301 \mathrm{pa}$ tients), 406 male patients, other than BC (691 patients) or those with unavailable diagnosis (349 patients), unavailable information about address $(1,202$ patients) and/or date of birth (2 patients), there were 6,393 patients identified in HER2 Registry available for matching with the Census database. By using gender, date of birth and address, we matched the HER2 Registry database with the Census database and we identified 33 Roma and 6,360 non-
-Roma female patients with BC. Further, we excluded those patients who did not have a complete pathology report and, finally, 32 Roma and 5,775 non-Roma women with $\mathrm{BC}$ were identified and used for the comparison of age at diagnosis, ASI (age-standardised incidence), and histology and biological characteristics.

Age distributions of study populations are presented in Tab. 1. The Roma BC patients were statistically significantly younger when compared with non-Roma BC women, with a median age of 49 years in Roma vs 61 years in non-Roma $(p=0.00001)$.

The $B C$ incidence rate was 17 and 36 per 100,000 people for Roma and non-Roma women, resp. Non-Roma BC women had 2.12 times higher ASIR (age-standardized incidence rate) than Roma.

The comparison of histology and biological characteristics between Roma and non-Roma BC patients is presented in Tab. 2. Roma had statistically significantly more hormone receptor negative (HR-) (34.4\% vs. $18.1 \%$; $p=0.03)$ and TN $(28.1 \%$ vs. $12.3 \% ; p=0.01)$ BC. Statistically significant difference, with more Roma than non-Roma having higher rate of HR- BC (Tab. 3) and TNBC (data not presented) was confirmed in multivariate analysis with age and HER2 status as co-factors. Roma women had 2.5 times higher odds to have a HR$B C$, independently of their age and 
Tab. 2. Biological characteristics of the analyzed populations.

\begin{tabular}{|c|c|c|c|c|c|}
\hline Variable & $\begin{array}{l}\text { Roma patients } \\
\text { absolute number }\end{array}$ & $\begin{array}{c}\text { Roma patients } \\
\text { (\%) }\end{array}$ & $\begin{array}{l}\text { Non-Roma patients } \\
\text { absolute number }\end{array}$ & $\begin{array}{c}\text { Non-Roma } \\
\text { patients (\%) }\end{array}$ & $\mathbf{p}$ \\
\hline all & 32 & 100.0 & 5,775 & 100.0 & NA \\
\hline $\begin{array}{l}\text { histology } \\
\text { invasive ductal carcinoma } \\
\text { other }\end{array}$ & $\begin{array}{c}27 \\
5\end{array}$ & $\begin{array}{l}84.4 \\
15.6\end{array}$ & $\begin{array}{l}4,687 \\
1,088\end{array}$ & $\begin{array}{l}81.2 \\
18.8\end{array}$ & 0.82 \\
\hline $\begin{array}{l}\text { HR status } \\
\text { positive for either } \\
\text { negative for both }\end{array}$ & $\begin{array}{l}21 \\
11\end{array}$ & $\begin{array}{l}65.6 \\
34.4\end{array}$ & $\begin{array}{l}4,731 \\
1,044\end{array}$ & $\begin{array}{l}81.9 \\
18.1\end{array}$ & 0.03 \\
\hline $\begin{array}{l}\text { HER2 status } \\
\text { positive } \\
\text { negative }\end{array}$ & $\begin{array}{c}4 \\
28\end{array}$ & $\begin{array}{l}12.5 \\
87.5\end{array}$ & $\begin{array}{l}1,036 \\
4,739\end{array}$ & $\begin{array}{l}17.9 \\
82.1\end{array}$ & 0.64 \\
\hline $\begin{array}{l}\text { HR and HER2 status } \\
\text { triple negative cancer } \\
\text { non-triple negative cancer }\end{array}$ & $\begin{array}{c}9 \\
23\end{array}$ & $\begin{array}{l}28.1 \\
71.9\end{array}$ & $\begin{array}{c}709 \\
5,066\end{array}$ & $\begin{array}{l}12.3 \\
87.7\end{array}$ & 0.01 \\
\hline
\end{tabular}

NA - not applicable, HR - hormone receptor

Tab. 3. Multivariate analysis of variables associated with hormone receptor negativity.

\begin{tabular}{|c|c|c|c|}
\hline Variable & OR & $95 \% \mathrm{Cl}$ & $\mathbf{p}$ \\
\hline $\begin{array}{l}\text { HER2 status } \\
\text { positive vs. negative }\end{array}$ & 2.70 & $2.32-3.15$ & $<0.01$ \\
\hline $\begin{array}{l}\text { age } \\
<50 \text { years vs. } \geq 50 \text { years }\end{array}$ & 0.90 & $0.76-1.06$ & 0.24 \\
\hline $\begin{array}{l}\text { ethnic status } \\
\text { Roma vs. non-Roma }\end{array}$ & 2.51 & $1.19-5.29$ & 0.02 \\
\hline
\end{tabular}

HER2 status $(95 \% \mathrm{Cl}$ for odds $1.19-5.26$; $\mathrm{p}=0.02)$.

\section{Discussion}

Roma people are one of the largest ethnic minorities living in Slovakia, but their health needs have been poorly studied. The factors that might explain ethnic health disparities were categorised into racial-genetic, health-behaviour, socio-economic, psychosocial stress and structural-constructivist models [27].

Studies searching for possible differences in cancer incidence, prevalence and mortality, and treatment outcomes in different ethnic groups have already been published [24-26,28-37]. There was, however, only few reports published on cancer in Roma [1,38].
The aim of our study was to compare the age at diagnosis, ASI (age-standardised incidence), and histological and biological characteristics between Roma and non-Roma BC women. For identifying the Roma women with $B C$, we used data from the Slovak HER2 Registry and the last SC2011.

The HER2 Registry collects pathology reports from the patients with breast tumors, and gastric and gastro-oesophageal cancer in Slovakia. There were 10,344 records entered in the HER2 Registry from 2011 through 2013. In 1,152 patients, more than one record was merged into one single record and thus 9,043 patients were identified. More than one record in one patient was caused by more than one examination of the histological sample (e.g. second-look review). Further, we excluded the patients with other than $\mathrm{BC}$ or unavailable histology, and male patients, and we identified 7,597 female $B C$ patients.

In the last report from the Slovak National Oncology Registry (NOR), where all new oncology cases in Slovakia are registered, there were 2,793 new females with BC registered in 2009 [39]. The absolute number of cases as well as ASI gradually increases each year. The absolute number of cases and ASI was 2,793 and 62.4 per 100,000 people, resp. in 2009. Based on data from NOR, we might expect approximately 9,000 new cases of BC in women in a 3-year period of time (from 2011 through 2013). We were able to identify 7,597 women with $\mathrm{BC}$, which is $84.4 \%$ out of 9,000 estimated 
new $B C$ patients and thus we assume that not all BC patients have been registered in HER2 Registry.

The SC2011 identified 5,404,322 people living in Slovakia and it is estimated that $99.36 \%$ of the whole population participated in the Census. There were 151,128 people who were recorded to have Roma nationality or to use the Roma language, and these people (2.8\% of the whole Slovak population) were identified as Roma [3]. Based on information from the Atlas of Roma Communities in Slovakia, the estimated number of Roma living in Slovakia is about 402,840 (7.46\%) [2]. The Atlas of Roma Communities identifies the Roma people living in Slovakia, in the segregated settlements, settlements on the edge of a town/village, settlements inside a town/village and Roma living dispersed in the majority population, and it lists more accurate information about the number of Roma people living in Slovakia.

Matching of the HER2 Registry database with the database from SC2011 was based on use of gender, date of birth and address information and thus we had to exclude 1,204 patients with unknown addresses and dates of birth. For matching the HER2 Registry and Census we used 6,393 patients in the HER2 Registry and 151,128 Roma people in the Census. We were able to identify 33 Roma and 6,360 non-Roma women with BC. Because the purpose of our study was to compare age at diagnosis, ASI, histological and biological characteristics between Roma and non-Roma women with $B C$, we further excluded 1 Roma and 531 non-Roma as their records were not complete. Finally, 32 Roma and 5,775 non-Roma women with $B C$ were identified for our analysis.

The median age of Roma women with $B C$ was statistically significantly lower when compared to non-Roma. According to the last data from SC2011, the mean age of Slovak men and women in 2014 was 38.24 and 41.43 years of age, resp., and the estimated life expectancy of Slovak men and women in 2014 was 73.19 and 80.00 years of age, resp. [3]. The mean age of Roma people registered in SC2011 was 23.52; that is more than
15 years lower than the mean age of the whole Slovak population. It is also estimated that the life expectancy of Roma people is more than 10 years lower than for non-Roma people $[1,3,40]$. In our study, the age of Roma women with $B C$ was statistically significantly lower and ASIR was 2.12 times lower than non-Roma.

There could be several explanations for the younger age of Roma women at diagnosis of BC. Firstly, as mentioned previously, we most probably could not identify all Roma BC patients in the HER2 Registry. This discrepancy could lead to unbalanced comparisons with statistical error caused by the relatively small sample number of Roma patients. The percentage of Roma patients was only $0.55 \%$ of all BC population identified in the HER2 Registry (32 out of 5,807 ) and thus it is most probable that some Roma patients were analysed in the group of non-Roma patients. Secondly, the median age when $B C$ is diagnosed in the general population is after 60 years of age. Therefore, we could expect that we will be less likely to diagnose older Roma women with BC, as Roma women tend to die younger. Thirdly, in the HER2 Registry, we identified $84 \%$ of the estimated new BC cases in women in a 3-year time period $(7,597$ out of 9,000). Thus, we might hypothesise that there might be an underreporting of Roma BC patients in the HER2 Registry, e.g. from some pathology departments that cover the areas where most Roma people live. Fourthly, there might be underdiagnosis of $\mathrm{BC}$ in older Roma women because of cultural, psychosocial or socio-economic reasons in comparison with younger Roma and thus we could not identify these Roma BC patients. Finally, there is also a possibility that older Roma women are less likely to admit their Roma nationality and so we could not identify older Roma women in SC2011 and thus in the HER2 Registry.

In our study, the age of Roma women with BC was statistically significantly lower and the ASIR was 2.12 times lower than non-Roma. The age-standardized incidence was 36 and 17 per 100,000 non-Roma and Roma, resp. Based on the last report of the NOR in
2009, ASI of BC in women was 62 per 100,000 people. As we were able to identify $64 \%$ of new BC women from the HER2 Registry, expected ASI would be 39.7 per 100,000 people, which is $64 \%$ out of 62 per 100,000 people. Expected ASI is thus comparable to our observation (36 women per 100,000 people). The observation of differences in ASIR between Roma and non-Roma BC women is different from the observation of higher incidence of $B C$ incidence in younger ( $<45$ years of age) African American women when compared to Caucasian American women [24-26]. It is probable that Roma women participate less than non-Roma in the screening programs and that lower participation could lead to a lower incidence rate of BC in Roma. In the United States' national surveys, approximately $70 \%$ of women age 40 years and older reported that they had a mammogram in the past 2 years. The rates varied by race/ethnicity and they were markedly lower among women with lower levels of education, without health insurance, and in recent immigrants $[41,42]$. It would be helpful to have information about TNM stage $[43,44]$ as we could expect that a lower attendance of the screening programmes would lead to a higher detection of disease in the more advanced stage. In our study, we did not analyse the differences in TNM stage as information about TNM stage was missing in almost $70 \%$ of nonRoma and most of the Roma patients (96\%). The reason for insufficient TNM data was the fact that TNM stage has not been systematically collected in the HER2 Registry because in many cases the pathologists do not have such information. There are certain risk factors that could be attributable to a higher incidence of BC in Roma, such as high BMI, early start of menarche and smoking history, but on the other hand there are some protective factors for $B C$, e.g. early age of the first pregnancy and low use of hormonal therapy that we would expect in Roma population [5]. The reports on breast-feeding patterns in Roma are contradictory [5]. We also cannot exclude statistical bias that might be caused by the low 
number of Roma identified for our analysis.

We observed a statistically significant difference between Roma and non-Roma $\mathrm{BC}$ patients in biological characteristics when Roma patients had more HR- and TNBC. The difference in HR status and TN retained its statistical significance when adjusted for age in multivariate analysis and, as well, Roma patients with HRand TNBC were statistically significantly younger. A similar observation was published about African American women whose $B C$ were more probably poorly differentiated and TN when compared with BC in white women [24-26]. It is estimated that $1: 40$ people of Ashkenazi Jewish ancestry carry one of three common founder mutations in $B R C A 1$ or $B R C A 2$ and this results in the hereditary breast and ovarian cancer (HBOC) syndrome [45]. Interestingly, there has been a report published about detection of 185 delAG BRCA 1 deletion in two Spanish Roma women that occurs with a high frequency in Ashkenazi Jews and this was the first report of such a mutation in a non-Jewish ethnic population. Such biological findings need to be further studied [38]. There is an $80 \%$ overlap between 'TN' phenotype and intrinsic 'basal-like' genotype [46]. Our observation of higher TNBC in Roma women could reflect higher incidence of $B R C A$ mutations, which are associated with a basal-like genotype [46]. A high coefficient of inbreeding in Roma was reported in the literature [1]. Many Roma still live in isolation from the majority population and that leads to reproductive isolation as well. Reproductive isolation could be a cause of a higher prevalence of certain genetic mutations and biological differences in $\mathrm{BC}$ in the Roma population and this would be worth further study.

In conclusion, we for the first time revealed differences in incidence and biological characteristics of Roma women with BC compared to non-Roma patients. Our data suggests that Roma patients are younger at diagnosis, have lower age-standardized BC incidence rate and more aggressive tumors compared to non-Roma. Further epidemiological and translational research trials are needed to identify the factors responsible for our observations.

\section{Acknowledgements}

We would like to acknowledge Dr. Gabriela Gogova Roche Slovakia for providing data from the Slovak HER2 Registry; Dr. Chakameh Safei from the Slovak National Oncology Registry for providing data from the Slovak National Oncology Registry; Dr. Zuzana Podmanicka and Dr. Pavol Skapik from the Statistical Office of Slovak Republic for providing data from the Slovak Census 201 Lucia Mrozova and Dana Janeckova for help with statistcal analysis; Prof. Kathryn Coe, Fairbanks School of Public Health, IUPUI, Indianapolis and Dr. Andrej Belak, Univer sity Pavol Jozef Safarik, Kosice for intellectual advice and Steve Zlatos, Esq. for English text revision. We would also like to acknowledge all contributors to the Slovak HER2 Registry.

\section{References}

1. Koupilová I, Epstein H, Holcík J et al. Health needs of the Roma population in the Czech and Slovak Republics. Social Science Medicine 2001; 53(9): 1191-1204.

2. Musinka A, Skobla D, Hurrle J et al. Atlas of Rom Communities in Slovakia 2013 [monograph on Internet]. United Nations Development Programme; 2014 [cited 2016 Jul 1]. Available from: http://www.minv. sk/?atlas_2013.

3. Matlovicova K, Matlovic R, Musinka A et al. The Roma population in Slovakia. Basic characteristics of the Roma population with emphasis on the spatial aspects of its differentiation. In: Penczse J, Radics Z (eds). Roma population on the peripheries of the Visegrad countries. Spatial Trends and social challenges. Debrecen 2012: 77-104.

4. Parekth N, Rose T. Health inequalities of the Roma in Europe: a literature review. Centr Eur J Public Health 2011 19(3): 139-142.

5. Cook B, Wayne FG, Valentine A et al. Revisiting the evidence on health and health disparities among the Roma: a systematic review 2003-2012. In J Public Health 2013; 58(6): 885-911. doi: 10.1007/s00038-013-0518-6.

6. Rosicova K, Reijneveld SA, Madarasova-Geckova A et al. Inequalities in mortality by socioeconomic factors and Roma ethnicity in the two biggest cities in Slovakia: a multilevel analysis. International J Equity Health 2015; 14(1): 123. doi: 10.1186/s12939-015-0262-z

7. Rosicova K, Madarasova-Geckova A, van Dijk JP et al. Regional socioeconomic indicators and ethnicity as predictors of regional infant mortality rate in Slovakia. Int J Public Health 2011; 56(5): 523-531. doi: 10.1007/s00038010-0199-3

8. Casals M, Pila P, Langohr K et al. Incidence of infectious diseases and survival among the Roma population: a longitudinal cohort study. Eur J Public Health 2011; 22(2) 262-266. doi: 10.1093/eurpub/ckq204.

9. Chalupa P, Jezek P, Privorova A et al. Viral hepatitis A in the catchment area of the Brno University Hospita 1983-1990. Cesk Epidemiol Mikrobiol Imunol 1992; 41(1): $2-7$

10. Gyarmarthy VA, Neaigus A, Ujhelyi E. Vulnerability to drug-related infections and co-infections among injecting drug users in Budapest, Hungary. Eur J Public Health 2009; 19(3): 260-265. doi: 10.1093/eurpub/ckp009.

11. Vantarakis A, Nearxou A, Pagonidis D et al. An outbreak of hepatitis $A$ in Roma populations living in three prefectures in Greece. Epidemiol Infect 2010; 138(7): 1025-1031. doi: 10.1017/\$0950268809991257.

12. Kojouharova M, Zuber PL, Gyurova S et al. Importation and circulation of poliovirus in Bulgaria in 2001. Bul World Health Organ 2003; 81(7): 476-481.
13. Maduma-Butshe A, McCarthy N. The burden and impact of measles among the Gypsy-Traveller communities, Thames Valle, 2006-09. J Public Health 2013; 35(1): 27-31. doi: 10.1093/pubmed/fds052

14. Dostal M, Topinka J, Sram RJ. Comparison of the health of Roma and non-Roma children living in the district of Teplice. Int J Public Health 2010; 55(5): 435-441. doi: 10.1007/s00038-010-0133-8.

15. Monasta L, Andersson N, Ledogar RJ et al. Minority health and small numbers epidemiology: a case study of living conditions and the health of children in 5 foreign Roma camps in Italy. Am J Public Health 2008; 98(11): 2035-2041. doi: 10.2105/AJPH.2007.129734.

16. Teira R, Suarez-Lozano I, Lozano F et al. Characteristics and outcome of HIV infection in gypsies in the Spanish VACH Cohort. Enferm Infecc Microbiol Clin 2010; 28(5): 266-272. doi: 10.1016/j.eimc.2009.04.018.

17. Hidvegi T, Hetyesi K, Biro L et al. Screening for metabolic syndrome within a minority ethnic group (adult Gypsy people) in Hungary. Bratisl Lek Listy 2011; 113(12): 721-724.

18. Vozarova de Courten B, de Courten M, Hanson RL et al. Higher prevalence of type 2 diabetes, metabolic syndrome and cardiovascular diseases in gypsies than in non-gypsies in Slovakia. Diabetes Res Clin Pract 2003; 62(2): 95-103.

19. Zivkovic TB, Marjanovic M, Prgomelja S et al. Screening for diabetes among Roma people living in Serbia. Croat Med J 2010; 51(2): 144-150.

20. Zjelko HM, Skaric-Juric T, Narancic NS et al. Traditional CVD risk factors and socio-economic deprivation in Roma minority population of Croatia. Coll Antropol 2008; 32(3): 667-676.

21. Gualdi-Russo E, Zironi A, Dallari GV et al. Migration and health in Italy: a multiethnic adult sample. J Travel Med 2009; 16(2): 88-95. doi: 10.1111/j.1708-8305.2008.00 280.x.

22. Carrasco-Garrido P Lopez de Andrés AL, Hernandez Barrera VH et al. Health status of Roma women in Spain. Eur J Public Health 2011; 21(6): 793-798. doi: 10.1093/eurpub/ckq153.

23. Ginter E, Krajcovicova-Kudlackova M, Kacala O et al. Health status of Romanies (Gypsies) in the Slovak Republic and in the neighboring countries. Bratisl Lek Listy 2001; 102(10): 479-484.

24. Brawley OW. Health disparities in breast cancer. Obstet Gynecol Clin North Am 2013; 40(3): 513-523. doi: 10.1016/j.ogc.2013.06.001.

25. Grenae C, Phelps MA, Villalona-Calero MA. Race and ethnicity in cancer therapy: what have we learned? Clin Pharm Therap 2014; 95(4): 403-412. doi: $10.1038 / \mathrm{clpt} .2014 .5$

26. Newman LA. Breast cancer disparities: high-risk breast cancer and African ancestry. Surg Oncol Clin N Am 2014. 23(3): 579-592. doi: 10.1016/j.soc.2014.03.014.

27. Dressler WW, Oths KS, Gravlee CC. Race and ethnicity in public health research: models to explainhealth disparities. Annu Rev Anthropol 2005; 34: 231-252.

28. Collins Y, Holcomb K, Chapman-Davis E et al. Gynecologic cancer disparities: a report from the Health Disparities Taskforce of the Society of Gynecologic Oncology. Gynecol Oncol 2014; 133(2): 353-361. doi: 10.1016/ j.ygyno.2013.12.039

29. Powel IJ. Prostate cancer in the African American: is this a different disease? Semin Urol Oncol 1998; 16(4): 221-226

30. Joshi AD, John EM, Koo J et al. Fish intake, cooking practices, and risk of prostate cancer: results from a multi-ethnic case-control study. Cancer Causes Control 2012; 23(3): 405-420. doi: 10.1007/s10552-0119889-2.

31. Reddy S, Shapiro M, Morton R et al. Prostate cancer in black and white Americans. Cancer Metastasis Rev 2003; 22(1): 83-86. 
32. Graham-Steed T, Uchio E, Wells CK et al. Race and prostate cancer mortality in equal-access healthcare systems. Am J Med 2013; 126(12): 1084-1088. doi: 10.1016/ j.amjmed.2013.08.012

33. Cykert S, Dilworth-Anderson P, Monroe MH et al. Factors associated with decisions to undergo surgery among patients with newly diagnosed early-stage lung cancer. JAMA 2010; 303(23): 2368-2376. doi: 10.1001/jama.2010.793.

34. Lathan CS, Neville BA, Earle CC. The effect of race on invasive staging and surgery in non-small-cell lung cancer. J Clin Oncol 2006; 24(3): 413-418.

35. Gordon HS, Street RL Jr, Sharf BF et al. Racial differences in doctors' information-giving and patients' participation. Cancer 2006; 107(6): 1313-1320.

36. DeDeugd C, Miyake M, Palacios DA et al. The influence on race on overall survival in patients with newly diagnosed bladder cancer. J Racial Ethn Health Disparities 2015; 2(1): 124-131.

37. Samson ME, Porter NG, Hurley DM et al. Disparities in breast cancer incidence, mortality, and quality of care among African American and European American women in South Carolina. South Med J 2016; 109(1): 24-30. doi: 10.14423/SMJ.0000000000000396.

38. Diez O, Doménech M, Alonso MC et al. Identification of the 185delAG BRCA1 mutation in a Spanish Gypsy population. Hum Genet 1998; 103(6): 707-708.

39. Krajcovicova I, Diba SC, Sieberova G et al. Cancer incidence in the Slovak Republic 2009 [monograph on the Internet]. National Health Information Center, National Cancer Registry Bratislava; 2015 [cited 2016 Jul 1]. Available from: http://www.nczisk.sk/Documents/publikacie/analyticke/incidencia_zhubnych_nadorov_2009.pdf.

40. Popper M, Szeghy P, Sarkozy S. Health and the Roma community: Analysis of the situation in Europe [monograph on Internet]. Partners for Democratic Change Slovakia 2009 [cited 2016 Jul 1]. Available from: http://www. gitanos.org/upload/13/60/Eslovaquia-corrected.pdf. 41. DeSantis C, Siegel R, Jemal A. American Cancer So ciety. Breast Cancer Facts \& Figures 2015-2016 [monograph on Internet]. American Cancer Society, Inc. 2015. [cited 2016 Jul 1]. Available from: http://www.can- cer.org/acs/groups/content/@research/documents/document/acspc-046381.pdf

42. Smigal C, Jemal A, Ward E et al. Trends in cancer by race and ethnicity: Update 2006. CA Cancer J Clin 2006; 56(3): 168-183.

43. Sobin LH, Gospodarowicz MK, Wittekind CH (eds). TNM classification of malignant tumors. 7th ed. Wiley-Blackwell 2009: 1-336.

44. Novak J, Fabian P. Comments on the TNM classification of malignant tumors -7 th edition. Klin Onkol 2011; 24(2): 149-150

45. Rosenthal E, Moves K, Arnell $C$ et al. Incidence of BRCA1 and BRCA2 non-founder mutations in patients of Ashkenazi Jewish ancestry. Breast Cancer Res Treat 2015; 149(1): 223-227. doi: 10.1007/s10549-014-3218-x.

46. Goldhirsch A, Winer EP, Coates AS et al. Personalizing the treatment of women with early breast cancer: highlights of the St Gallen International Expert Consensus on the Primary Therapy of Early Breast Cancer 2013. Ann Oncol 2013; 24(9): 2206-2223. doi: 10.1093/annonc/mdt303. 